\title{
Francisco Toledo, sus inicios
}

\section{Francisco Toledo, Beginnings}

Artículo recibido el 6 de abril de 20I6; devuelto para revisión el I7 de agosto de 20I6; aceptado el I6 de mayo de 2017, http://dx.doi.org/IO.2220I/iie.18703062e.2017.III.26IO

Carlos A. Molina P. Universidad Autónoma Metropolitana-Cuajimalpa, México. mopc740723@yahoo.com

Líneas de investigación Cultura visual en el siglo xx-historia y museos.

Lines of research $\quad 20^{\text {th }}$ Century Visual Culture-Museums and History.

Publicaciones más relevantes "Fernando Gamboa y su particular versión de México", Anales del Instituto de Investigaciones Estéticas XXVII, núm. 87 (otoño 2005), http://dx.doi.org/I0.2220I/iie.18703062e.2005.87.2194; La Colección Andrés Blaisten de México (México: Universidad Nacional Autónoma de México/Turner/El Equilibrista, 2006), www.museoblaisten.com; Diana C. Du Pont, ed., Tamayo: A Modern Icon Reinterpreted, catálogo de la exposición (Santa Barbara Museum of Art/Turner Libros, 2007); "Arquitectura, arte y coleccionismo en México", Arquitectónica (primavera, 20I2).

Resumen En este artículo se observa el desarrollo de la obra de Francisco Toledo entre 1953 y 1963, rastreando aprendizajes e influencias entre Oaxaca y París. Se proponen de este modo I2 apuntes temáticos para abrir una conversación sobre los inicios de su obra gráfica.

Palabras clave Francisco Toledo; gráfica; Rufino Tamayo; París; Oaxaca.

Abstract The article addresses the development of Francisco Toledo's work between 1953 and 1963 , tracing his artistic influences and training between Oaxaca and Paris. A dozen thematic sketches are suggested with the aim of generating discussion regarding the beginning of Toledo's graphic art.

Keywords Francisco Toledo; graphic; Rufino Tamayo; Paris; Oaxaca. 
DOI:http://dx.doi.org/10.22201/iie.18703062e.2017.111.2610. 


\author{
CARLOS A. MOLINA P. \\ UNIVERSIDAD AUTÓNOMA METROPOLITANA-CUAJIMALPA, MÉXICO
}

\title{
Francisco Toledo, sus inicios
}

$\mathrm{E}$ xisten dos vías fundamentales para rastrear un mito de origen en la obra de Francisco Toledo. La primera recoge indicios de su biografía, a mitad del camino entre lo que el artista admite y lo que de él se deriva a partir de diversa documentación y conversaciones con quienes lo han conocido. La otra surge del análisis de sus imágenes, certidumbres y estaciones para así establecer una cronología de desarrollos e influencias. Debido a que no existe un exhaustivo y necesario catálogo razonado como punto de partida para realizar un estudio propiamente iconográfico, el objetivo de este artículo es señalar rasgos claros en la técnica y proponer un debate desde una muestra limitada

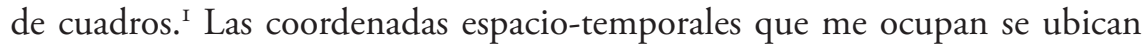
alrededor de 1953 y I963, es decir, entre su partida de Oaxaca — para encontrar su vocación artística-, el aprendizaje en un ámbito gremial en París y el diálogo con Rufino Tamayo. Para esta última etapa es necesario esclarecer en ambos pintores el entendimiento de una premisa esencialista que los reputa como intrínsecamente oaxaqueños y que parecen compartir. Se apuesta aquí por un tejido que imbrica lo particular y anecdótico en Toledo, con una serie

I. Las obras de las que parto son: Sin título, 1960, $50.8 \times 45 . \mathrm{I} \mathrm{cm}$, técnica mixta, Davidson Galleries, Seattle, Washington, EUA; Chapulin tocando el arpa, 1959, acuarela y collage sobre papel, $64.5 \times 49.5 \mathrm{~cm}$, Blanton Museum of Art-Austin, Texas, EuA; Orgía, 1963, acuarela sobre papel, $48 \times 66 \mathrm{~cm}$, Blomqvist Kunsthandel AS, Oslo, Noruega. En 2013, Fomento Cultural Banamex inició un proyecto museográfico y editorial para el que reunió una vasta muestra de obra de Francisco Toledo (Juan Rafael Coronel Rivera, Alberto Blanco, David Huerta y Gonzalo Vélez, Francisco Toledo. Obra I957-1990, 2 t. (México: Fomento Cultural Banamex, 20I6). Este artículo debe mucho a conversaciones que en el marco de aquellas investigaciones tuvimos Cándida Fernández, Juan Coronel Rivera, Renato González Mello y yo. 
de apuntes generales sobre la gráfica hacia 1960, la geopolítica del arte y la elucubración de influencias y ascendientes que los cuadros anuncian.

\section{El origen}

En la década de los años cincuenta había una manera de hacer y conocer la pintura en nuestro país, favorecida por los más exitosos artistas y adoptada como oficial por el Estado. Esa forma de representación colapsaba en un solo referente al proletariado (fundamentalmente campesino y protagonista de la guerra civil, pero también al industrial y habitante de la urbe actual), a la trama discursiva del nacionalismo revolucionario (justificación ideológica única del poder y marco conceptual ciudadano para entender el país que se construía tras el conflicto de I9IO) y a un elemento indígena rural (especie de arcadia bucólica mexicana y admiración del indio como ubicación primordial y conjunto mayoritario de la población). Esta suerte de "realismo socialista" en una advocación mexicana, es obra fundamental del muralismo y del Taller de Gráfica Popular (TGP). ${ }^{2}$ Ésos son los colectivos de artistas que funcionan como discurso oficial del arte y su contrapunto. El núm. I8 de Artes de México celebraba en 1957 los veinte años del Taller de Gráfica Popular. ${ }^{3}$ Ello prueba la importancia que la gráfica tenía para el mundo del arte en México en aquel entonces, aunque parezca desde la promoción oficial que propugna a los Tres Grandes (David Alfaro Siqueiros, Diego Rivera y José Clemente Orozco), que se tratara de un género menor.

En ese colectivo de grabadores, muy activo pero poco agraciado desde los encargos del gobierno, se vivía de ventas al detalle para el turismo cultural norteamericano y de pedidos propagandísticos para el sindicato ferrocarrilero o el

2. James Oles, al discutir la Madre proletaria, de David A. Siqueiros (I93I), y la Molendera, de Diego Rivera (1924), califica ambos ejercicios de "pintura realista de contenido social [...] artes triunfalistas de origen soviético", en Olivier Debroise y James Oles, Retrato de una década I9301940: David Alfaro Siqueiros, catálogo de la exposición (México: Instituto Nacional de Bellas Artes-Consejo Nacional para la Cultura y las Artes-Museo Nacional de Arte, 1996), I2I-I36. Veáse también Leonor Morales García, "El Taller de Gráfica Popular y su vinculación con el realismo socialista”, en Primer Coloquio del Comité Mexicano de Historia del Arte. Arte y coerción (México: Universidad Nacional Autónoma de México-Instituto de Investigaciones Estéticas, 1992), 205-220.

3. Según Leonor Morales García (en Arturo García Bustos y el realismo [México: Universidad Iberoamericana, 1992]) este número de la revista Artes de México estuvo dedicado a Arturo García Bustos. 
de electricistas. ${ }^{4}$ Allí, un militante del Partido Comunista Mexicano y miembro del TGP a partir de 1947, Arturo García Bustos, formaría parte de ese pequeño grupo de artistas alumnos de Frida Kahlo en La Esmeralda, durante la dirección de Antonio Ruiz, El Corcito, conocidos también como Los Fridos (junto a Guillermo Monroy, Fanny Rabel y Arturo Estrada). García Bustos había regresado en 1954 de la aventura en Guatemala con el régimen de Jacobo Árbenz y a donde había llegado con la promoción de Luis Cardoza y Aragón. ${ }^{5}$ Debió ser el primer docente que puso a Francisco Toledo en contacto con el hacer y el pensar del arte, cuando fuera su maestro de grabado en linóleo durante la Secundaria en el otoño de 1952 y a quien García Bustos y su esposa, Rina Lazo, luego encontrarían de nuevo en la Escuela de Bellas Artes en la primavera de $1955 .{ }^{6}$ El contacto con Toledo debió darse otra vez en la Biblioteca de la Universidad de Oaxaca, en el marco de la exposición "Testimonio de Guatemala” (del ig al 3I de diciembre de 1954) y cuyo catálogo redactó Cardoza y Aragón.7 En aquellas clases el matrimonio de profesores tenía asumido, como compromiso ético número uno, despertar la conciencia social de sus discípulos. ${ }^{8}$

Han sido referencias frecuentes como principio para unos apuntes biográficos de Toledo publicados aquí y allá, la raigambre indígena, la pérdida del padre, el universo oaxaqueño y sucesivos trasterramientos. ${ }^{9}$ Pero lo cierto es que ninguno de estos temas aparece como constante en su obra, no al menos en los años que comprenden estas páginas. Estamos frente a un mito ausente. Aun-

4. Helga Prignitz, El Taller de Gráfica Popular 1937-1977 (México: Instituto Nacional de Bellas Artes, 1992), 34-47.

5. Luis Cardoza y Aragón, Ojolvoz, Biblioteca Era (México: ERA, I988), IO5.

6. Jorge Alberto Manrique, “Toledo: el gusto por la vida”, en ed. Verónica Volkow, Francisco Toledo (México: Smurfit Cartón y Papel de México, 2002), II-24.

7. Leonor Morales García, "Arturo García Bustos y el grabado comprometido", tesis de maestría en Historia del Arte (México: Universidad Nacional Autónoma de México-Facultad de Filosofía y Letras, I988), 4I-43.

8. Raquel Tibol, “¿Qué piensan los misioneros del InBA?: Rina Lazo y García Bustos en Oaxaca", en "México en la Cultura", suplemento de Novedades, núm. IO4, 24 de marzo de 1957, 2-8.

9. Veáse, por ejemplo: Blanca Gutiérrez Galindo, "Francisco Toledo: historia y naturaleza”, tesis de maestría en Artes Visuales (México: Universidad Nacional Autónoma de México-Escuela Nacional de Artes Plásticas, 1996), I78; Esther Morales Maita, "Francisco Toledo: mito y leyenda", Boletín Antropológico, núm. 60 (enero-abril, 2004), I23-I37; Dore Ashton, Francisco Toledo (Los Ángeles: Latin American Masters, 199I), 231; Luis Carlos Emerich y Carlos Monsiváis, Francisco Toledo: obra gráfica para Arvil (México: Consejo Nacional para la Cultura y las Artes-Instituto Nacional de Bellas Artes, 200I, I67); s.p.; Francisco Toledo: exposición retrospectiva, 1963-1979 (México: Instituto Nacional de Bellas Artes, 1980), 72. 
que los estudiosos recurran a aquellas circunstancias para explicarse al pintor, él mismo no las incluye en su pintura, le resultan irrelevantes. Ciertamente hubo un momento de su infancia en el que llegó a un Minatitlán que era manglar y selva, desconectado por completo del resto del mundo. Allí no había caminos, los animales y las personas parecían compartir el paisaje, andaban desnudas; Francisco las recuerda cantando por ninguna razón. ${ }^{10}$ Después de dejar esa primera infancia, cuando la figura del progenitor dejó de existir, Toledo comenzaría a cobrar conciencia propia en la ciudad de Oaxaca, un pueblo grande y con profundidad histórica suficiente como para ser escenario de etapas sucesivas y fundacionales de la historia nacional (la raíz prehispánica, el legado colonial y el logro de la soberanía). Cuando adolescente emigra a la capital del país y de ahí, del Distrito Federal, hace vocacional peregrinaje a la capital de la Antigüedad: Roma.

Con la mayoría de edad llegaría finalmente a París, sede de la modernidad y su arte. Pero no existen ni en su obra ni en el relato de sí mismo, instantes de pasmo, hallazgo ni mención más allá de lo incidental que sugiera un tropo metropolitano. En ninguna parte Toledo cuenta la revelación del "Gran Arte" al novicio. Ése sería el relato esperado que imbrica al individuo con su circunstancia, pero no. No pueden leerse en su obra glosas ni homenajes a la historia del arte que sin duda vio en Europa. Esas urbes, como alusión e insoslayable referente, no están en su obra.

\section{La metrópolis}

El cuento donde un sujeto intrascendente supera toda adversidad imponiéndose a su propio destino, a la dinámica y peligros de la capital, el heroísmo del recién llegado a la ciudad, es una tradición que puede remontarse al Oliver Twist (I837-1839) de Charles Dickens y en México tiene su más clara personi-

Io. Entrevistas con Francisco Toledo; Jan Martins Ahrens en "Quise ser un ilustrador de mitos", en "Miradas latinas", "El País Semanal", suplemento de El País, 26 de agosto de 20I5, consultado el I de febrero de 2016, en http://elpais.com/elpais/2015/08/I4/eps/I439563519_0636r9.html; David Martín del Campo, "Las sandalias del pintor”, Lourdes Zambrano, entrevista, El Diario de Palenque, 3 de septiembre de 20I4, consultado el ro de septiembre de 20I5, en http://www. diariodepalenque.com.mx/2014/og/las-sandalias-del-pintor/. 
ficación en el advenimiento historiográfico de Benito Juárez. ${ }^{\mathrm{II}}$ Otros exponentes de cierta fascinación con el trajín citadino y su magnitud, el edificio y la verticalidad, son los vanguardistas del estridentismo (I92I-1927). ${ }^{12}$ A Rufino Tamayo sí le pasó ese trance con la gran ciudad, lo mismo pintando los tranvías en Indianilla y los aviones de Balbuena, que de visita en Nueva York con Carlos Chávez hacia 1927. ${ }^{13}$ Pablo Picasso, Georges Braque y Diego Rivera hicieron de tal descripción de lo citadino, manifiesto estético. Cito a estos artistas porque sin duda eran conocidos por Toledo. El apunte sirve para insistir en que ni desde la influencia de otros ni desde la vivencia propia Toledo se fascina con el carácter cosmopolita. No vemos en sus cuadros mapas, siluetas, croquis, sonidos, olores, movimiento; ninguna de las cualidades sociales o psicológicas del encuentro con la gran ciudad. ${ }^{\mathrm{I}}$ Toledo parece estar ensimismado siempre, concentrado en un repertorio que tiene claro esté donde esté. Su obra, entonces, no refleja del plano hacia afuera, más bien explora qué hay en la superficie y para adentro. Él no está ocupado con un ejercicio imitativo, no es mímesis lo suyo. ${ }^{15}$ Cada cosa allí representada es un símil (la figura retórica que traza semejanzas) para esa escena, indefinido proceso mágico que hay en la naturaleza y el acercamiento a su comprensión por parte de los hombres. Rara vez hay en esta primera etapa de Toledo una historia narrada en sus cuadros. Aquella fue una época en la que le importaba más lo material en el sentido último de la palabra. Ese significado procede de mater y comparte significantes con lo originario, lo natural, el color de los animales, la textura de lo vege-

II. Al respecto véase: Mauricio Tenorio Trillo, Artilugio de la nación moderna: México en las exposiciones universales, I880-1930 (México: Fondo de Cultura Económica, 1998), 39-55.

I2. Hay incontables referencias en Manuel Maples Arce, Fermín Revueltas, Ramón Alva de la Canal, Leopoldo Méndez, entre otros, a Estridentópolis, las máquinas, las explosiones obreriles. Véase sus manifiestos y Elissa J. Rashkin, The Stridentism Movement in Mexico: the Avant-Garde and Cultural Change in the Igros (Plymouth: Lexington Books, 2009).

I3. Yael Bitrán Goren, Diálogo de resplandores: Carlos Chávez y Silvestre Revueltas, Ríos y Raíces (México: Consejo Nacional para la Cultura y las Artes-Instituto Nacional de Bellas Artes, 2002), 19-28.

I4. Nelson Goodman, “On Capturing Cities”, Journal of Aesthetic Education 25, núm. I (primavera, 199I): 5-9.

I5. Empleo el término en su entendimiento más básico, aquello que Benjamin calificara de "la facultad del hombre para producir similitudes", en Walter Benjamin, "On the Mimetic Faculty”, en Reflections (Nueva York: Schocken Books, I986 [1933]), I37; para una introducción al debate gremial que el término implica recomiendo la entrada mimesis del glosario de términos teóricos para estudios mediáticos de la Universidad de Chicago, escrito por Michelle Puetz, 2002, consultado el I2 de diciembre de 20I5, en http://csmt.uchicago.edu/glossary2004/mimesis.htm 
tal, las sensaciones más primarias. Lo expresivo allí es para los sentidos y no para el intelecto; Eduardo Subirats la ha llamado "experiencia numinosa" en la pintura de Toledo. ${ }^{16}$

En la Ciudad de México de 1957 en la que ocurre un importante movimiento telúrico, hecho extraordinario que tampoco pinta ni menciona, Toledo es un estudiante juchiteco que ronda las escuelas de formación artística en busca de oportunidad o vocación. Las inscripciones para la Academia de San Carlos y La Esmeralda habían pasado y ésa parece ser la única circunstancia que explique su ingreso a la Escuela de Diseño y Artesanías del InBa. ${ }^{17}$ La Memoria del Instituto Nacional de Bellas Artes 1958-1964 reporta que esa escuela no era menor, tenía tantos como 39 maestros y una población de 836 alumnos. ${ }^{18}$ Guillermo Silva Santamaría, el maestro de Toledo en Oaxaca entre 1953 y 1955, era un surrealista colombiano, cuya técnica peculiarísima lograba tridimensionalidad en las placas yuxtaponiendo tintas y etapas de impresión. En 1959, justo al salir Toledo hacia Europa, Silva Santamaría era el encargado del Taller de Grabado en Metal del Centro Superior de Artes Aplicadas. En el ámbito institucional, Carlos Alvarado Lang era el jefe del Taller de Calcografía y Grabado. ${ }^{19}$

En 1949 José Chávez Morado había comenzado a operar el Taller de Integración Plástica, auspiciado por la Secretaría de Educación Pública y donde, más allá de la pretensión programática que intentaba hacer arte público en la forma de esculturas monumentales y murales, se experimentaba día a día una forma inusitada de trabajar: no había allí jerarquías, ni sistemas, se trataba de una labor horizontal muy a la usanza de un taller. ${ }^{20}$ Sin juzgar aquí los alcances o éxitos de la "integración plástica" y su consecución en Ciudad Universitaria, lo que resulta relevante para la figura de Toledo es el ambiente de colectividad que momentáneamente observaría aquel adolescente oaxaqueño,

I6. Eduardo Subirats, "La resistencia estética", Arquitextos 5, núm. I23, año II, 8 de agosto de 20Io, ed. Guerra, Brasil, consultado el is de junio de 20I4, en www.vitruvius.com.br/revistas/ $\mathrm{read} /$ arquitextos/II.123/3503

17. Sonia Ávila, "Escuela de Diseño y Artesanías busca su consolidación [entrevista a su directora, Berenice Miranda]", "Expresiones es Cultura", suplemento de Excélsior, 6 de agosto de 20II, año XCVI, t. II, núm. 34I40, 7-8.

I8. Memoria de Labores del Instituto Nacional de Bellas Artes 1958-1964 (México: Secretaría de Educación Pública-Instituto Nacional de Bellas Artes, 1964), 22.

19. Memoria de Labores del Instituto Nacional de Bellas Artes, organigrama, anexo en la segunda de forros.

20. José de Santiago, José Chávez Morado. Vida, obra y circunstancias (Guanajuato: La Rana, 200I), 397. 
que conocía solamente rudimentos de grabado y del que hallaría continuidad una vez en París. De esa misma manera, transversal e igualitaria, funcionaron el Movimiento de Integración Plástica y el Taller de Artesanos. ${ }^{21}$ En ambas instancias colaboraron los primeros maestros de Toledo en la Ciudad de México: Raúl Cacho y José Chávez Morado. Cacho había trabajado en 1940 con Hannes Meyer, el emigrado de la Bauhaus, de allí la convicción sobre el esquema grupal y llano en la enseñanza artística. ${ }^{22}$ En el Centro Superior de Artes Aplicadas se seguía un Taller de Grabado y Estampa al que acudió Toledo. Entre los profesores figuraban Carlos Alvarado Lang para Grabado en Hueco, Arturo García Bustos impartía Estampa a la Manera China, José Chávez Morado y Leopoldo Méndez se turnaban Grabado en Relieve, Fernando Leal daba Historia del Arte y Rina Lazo dirigía una materia llamada Dibujo Aplicado. ${ }^{23}$

\section{El buen salvaje}

Algunos apuntes, rescatados de aquí y allá, en su relato autobiográfico parecen contestar con algún dejo de ironía o aceptación sardónica las historias tejidas en torno suyo. Por ejemplo, cuando platica a cámara la historia de "El Rojo", el mico protagonista del relato kafkiano, invención a dúo y que compone junto a su hija Laureana, dice: "en la historia del mono que aprendió... ése soy yo". ${ }^{24}$ El mito del "buen salvaje" es un tropo constantemente empleado en el siglo xIx para exponer el mutuo hallazgo que un occidental y la otredad cultural hacen, uno del otro. Allí la narrativa colonialista intenta apropiarse del no-europeo así "descubierto" y consecuentemente aquel nativo de los nuevos territorios hará un juego de adopciones y resistencias al enfrentarse con el relato hegemónico que intenta una doble operación de comprensión y some-

2I. Louise Noelle, "La integración plástica: confluencia, superposición o nostalgia", en Lucero Enríquez, ed., XXII Coloquio Internacional de Historia del Arte (In)disciplinas. Estética e historia del arte en el cruce de los discursos (México: Universidad Nacional Autónoma de México-Instituto de Investigaciones Estéticas, 1999), 537-55I.

22. Pablo Lazo, "Dislocating Modernity: Two Projects by Hannes Meyer in Mexico", en $A A$ Files, núm. 47 (verano, 2002) (Londres: Architectural Association School of Architecture): 57-63.

23. Memoria de Labores del Instituto Nacional de Bellas Artes 1954-I958, 26.

24. Albino Gómez Álvarez, dirección y producción, El informe Toledo (México: Canana/Lo Otro Producciones, 2009, film-animación; $82 \mathrm{~min}$ ). A partir del relato breve de Franz Kafka, Un informe para una academia, 1917; el parlamento específico aquí referido se encuentra entre el minuto 9' I3" y el 9'i6". 
timiento. La fe decimonónica en el evolucionismo y la historia universal explican desde esta premisa la llegada del "salvaje" a una circunstancia "civilizada" y los modos en que se adecua o conforma a esa nueva vida. ${ }^{25}$ Para la narrativa del bon sauvage es igualmente relevante la epopeya del traslado, es decir, la lejanía y dificultad con que se alcanza la civilización partiendo desde la selva y cuya anécdota es fundamental en la conformación del biografiado. Justamente cuando Francisco Toledo viajó a París cambiaron la aeronave, la duración, las escalas y la experiencia de un vuelo trasatlántico. ${ }^{26}$ Pero tampoco le interesa, no hay en Toledo representación del viaje ni del destino o las paradas. Es el hacer de su pintura lo que le importa.

Teresa del Conde recoge un antecedente rara vez mencionado para ubicar el principio de Toledo como artista, la exposición entre diciembre de 1958 y enero de 1959 titulada "Nuevos exponentes de la pintura mexicana" que se celebró en el Museo Universitario de Ciencias y Artes de la UnAM. Allí se ofreció al público obra de Juan Soriano, Manuel Felguérez, Enrique Echeverría, Vicente Rojo, Benito Messeguer y Toledo mismo. ${ }^{27}$ La crónica de la exposición aparecida en la Revista de la Universidad advierte que Toledo: "dibuja con la genialidad y las limitaciones de un niño", para explicar cierto primitivismo hallado en su obra. ${ }^{28}$ Se advierte además que quienes más llaman la atención ahí son Toledo y Lilia Carrillo.

Una diferencia fundamental entre la obra de Francisco Toledo y la de Lilia Carrillo, a quienes se ha citado juntos como germen de cambio a finales de los cincuenta y principios de los sesenta, radica en que la "abstracción geométrica” de la capital sigue un proceso cézanneano, mientras que en la figuración del oaxaqueño preside siempre el croquis lineal. Carrillo procede de una mancha de color que se volverá en el proceso de la obra, su bosquejo. Es decir, no halla diferencia entre la pintura final y su trazo formal primero. Sigue a aquel

25. Peter Fritzsche, "Specters of History: On Nostalgia, Exile and Modernity", The American Historical Review I06, núm. 5 (diciembre, 200I): I-40.

26. El tetramotor Super-Constellation que partía de la Ciudad de México hacía escala en Nueva York-LaGuardia, luego en Gander, en el extremo de Terranova, saltaba el Atlántico hasta Shannon en Irlanda y finalmente llegaba a París-Orly en casi 36 horas de vuelo efectivo. En el invierno de 1959, AirFrance comenzó a operar el primer jet Caravelle, que reducía el viaje a tres tramos de nueve horas cada uno duplicando el número de pasajeros.

27. Teresa del Conde, "Francisco Toledo como artista gráfico", Anales del Instituto de Investigaciones Estéticas XV, núm. 60 (1989): I43-162.

28. Ventura Gómez Dávila, "Nuevos exponentes de la pintura mexicana", Revista de la Universidad de México, núm. I (septiembre, I959): 2I-22. 
esbozo un contraste tonal y una serie de texturas que eliminan por completo todo rastro dibujístico. Allí Carrillo persigue dos influencias fundamentales, Manuel Felguérez por lo inmediato, Zao Wou-Ki como contraparte culturalmente remota. ${ }^{29}$ Francisco Toledo raya el itinerario de su pintura y ese esqueleto no se abandona ni transforma nunca. Esos primeros trazos son certidumbre al principio, demostración al final de cada obra. Rufino Tamayo, interlocutor respetado de Toledo en París, apreciaba también la obra de Carrillo por aquel entonces y seguramente la incluye en sus pláticas. Carrillo asiste a la Académie de la Grande Chaumière en 1953 y está de vuelta en México cuando Toledo busca escuela hacia 1957. Son los años en los que ambos dialogan con Antonio Souza como galerista y amigo. ${ }^{30}$

\section{Moderno}

Los diversos momentos constitutivos de cada cuadro en Toledo son la precisión de coordenadas con las que ubica su identidad compleja, el imbricado universal, social y comunitario inteligible en su obra. La personalidad asumida de Toledo como juchiteco, los rastros zapotecos en su pintura son un ejercicio de reflexión a posteriori (el artista se reconoce mestizo, aquella no fue su lengua nativa, nunca fue campesino y viajó a Europa en una misión conscientemente formativa), es elección y ficción del ser asumida frente a su propia trayectoria y los influjos culturales que corren por su obra. ${ }^{3}$ Ello en el contenido, en lo formal, en cambio, su búsqueda de valores plásticos dialoga con la modernidad occidental que vive hacia 1960. Refiere, por ejemplo, haber visto cliché-verres en París y años después discutir con Manuel Álvarez Bravo esa técnica, aquellos efectos de transparencia, textura y superposición de superfi-

29. Margarita Martínez Lámbarry, "Lilia Carrillo (I930-I974) —remembranza”, Discurso Visual, núm. I (julio-septiembre, 2004) [Nueva Época], consultado el I6 de junio de 20I4, en http:// discursovisual.net/dvweboi/remembranza/remmartinez.htm.

30. Teresa del Conde, "La aparición de la Ruptura", en Un siglo de arte mexicano: 1900-200o (México: Instituto Nacional de Bellas Artes-Consejo Nacional para la Cultura y las Artes/Landucci Editores, I999), I-20.

31. Ello se desprende de la conversación que tuviera con Renato González Mello y Cuauhtémoc Medina en el IAGO en I994, veáse "Entrevista exclusiva con Francisco Toledo", Viceversa, núm. I8 (noviembre, I994): 6-I4. 
cies que permite la manipulación de la fotografía con vidrio como sustrato. ${ }^{32}$ En tales ejercicios no hay una idea previa, es experimentación pura, es mezcla de grabado dibujando sobre la superficie, pintura en su sentido más amplio y hallazgo con los químicos, la luz y su eventualidad en la fotografía.

En resumen, para la época hay un juego de incongruencias que sirve como dispositivo de explicación, en el cual la mexicanidad compartida por piezas precolombinas y los Rivera o los Siqueiros, en los montajes de Fernando Gamboa, existe en una ahistoricidad limitada, no obstante, por la ubicación de lo azteca y la mitad del siglo xx. La obra de Toledo se desarrolla en otro registro, en otra dimensión temporal, una que es eterna y más allá de coordenadas historizables, ésa que conecta la representación del hombre prehistórico con un carácter intemporal y propio de aquellas imágenes cuya naturaleza se reconoce como esencialmente artística. A ese mismo respecto Luis Cardoza y Aragón decía que no había "designios folklóricos" pese a un "no sé qué regusto indígena" cuando compara el sabor local y oaxaqueńo de Toledo con la peculiaridad eterna que salta a la vista como "primitivismo gráfico" y su "originalidad raigal". ${ }^{33}$ Jorge Alberto Manrique se ha referido a esa misma característica como una invitación en la que "Nos invita a volver a instaurar un modo mítico de relación con las cosas". ${ }^{34}$ Se alude así a una supuesta elocuencia que distingue al buen-salvaje en la narrativa de Occidente, un regreso a cierta visión perdida y que convendría recuperar. ${ }^{35}$ Dicha premisa ideológica y discursiva con la que se le ligará desde entonces es su condición de trasterrado. De piel oscura y aspecto desgarbado en un clima de polvorín político entre Francia y Argelia, Roberto Donís refiere que con frecuencia los detenían y los gendarmes asumían que eran árabes sin papeles. ${ }^{36}$ Toledo no asume las coordenadas de mexicanidad usuales entre los connacionales en el extranjero, pero su personaje invita a la lectura del buen salvaje en lucha con el ser de la modernidad. Allí mismo reconoce estar aislado en Europa, sentirse aparte, tener nostalgia. Pero no lo refleja en su práctica pictórica. Esa identidad y raigambre, la del indio, que no es tema o preocupación para él, se vuelve relevante, sin embargo, para quienes empiezan a conocerlo.

32. Gina Mejía, "IAGo: un proyecto generoso", en El Imparcial. El mejor diario de Oaxaca, "Suplemento Especial", Oaxaca: noviembre, 2013, 5-7.

33. Luis Cardoza y Aragón, Pintura contemporánea de México (México: ERA, 1974), 29-30.

34. Manrique, "Toledo: el gusto por la vida", I3.

35. Edna C. Sorber, “The Noble Eloquent Savage”, Etnohistory 19, núm. 3 (verano, 1972): 227-236.

36. Germaine Gómez Haro, "Roberto Donís: in memoriam", en suplemento "LaJornada Semanal", "Arte y Pensamiento", sección de La Jornada, núm. 696, 6 de julio de 2008, I3. 
Aunque muchos de los animales y algunas anécdotas provengan del imaginario zapoteca, ninguna de aquellas estampas pretende explicar ese ámbito mítico y se conforma con ser mera ilustración. La obra de Toledo entonces es un material etnográfico de frontera entre lo indígena milenario y la contemporaneidad de su autor. No está allí la formulación canónica con que Claude Lévi-Strauss distingue al mito de otros materiales recogidos por el antropólogo o el turista. ${ }^{37}$ No se esclarecen desde la pintura ni la gráfica de Toledo estados del cuerpo ni sus procesos, no hay construcciones que den coherencia al edificio espacio-temporal de lo oaxaqueño ni se infiere clasificación social alguna, tampoco se simbolizan estructuras político-religiosas. Al no existir dicha teleología en el trabajo de Francisco Toledo tenemos que su obra simplemente vuelve objeto plástico lo que observa o le fue contado. Se sitúa entonces a un paso de la realidad referida; es oficio de artesano y su contemplación precisa distancia, allí sólo su autor asume como propio lo que mira, lo pinta y lo ofrece sin más.

\section{Artista}

La primera exposición de Toledo es aquella mítica en la calle de Berna en la Ciudad de México y su corresponsalía misteriosa en Dallas-Fort Worth. Toledo reconoce en Antonio Souza una influencia primordial, el galerista tenía una idea clara del mundo del arte que compartió con el oaxaqueño y que lo encaminó para dedicarse de lleno a dicha vocación y su mercado. En una entrevista con Elena Poniatowska, Toledo concede que Souza lo rebautice como "Francisco", le da la dirección de Tamayo en el Quartier Latin y del diálogo con ambos personajes es cómo entiende qué es "posicionarse" como artista. ${ }^{38}$ En esa etapa

37. Mark S. Mosko, "The Canonic Formula of Myth and Non-myth", American Ethnologist I8, núm. I (febrero, I99I): I26-I5I.

38. Elena Poniatowska, "Francisco Toledo-II y última”, en La Jornada, domingo, i8 de julio de 20I0, contraportada, año XXVI, núm. 9313, consultado el 2 de enero de 20I4, www.jornada. unam. mx/2010/07/18/opinion/ao4arcul. Por otro lado, positioning es un anglicismo proveniente de la mercadotecnia y que supone imbricar la explotación de un nicho en el mercado [producto], ofertar allí como único un insumo o producto dado [promoción], desarrollar una marca y sostener estrategias de venta a largo plazo. En gran medida se parece a lo que Souza y Tamayo le explican a Toledo que debe hacer con su obra: distinguirla del resto de los mexicanos y la oferta galerística, hallar la manera de tejer las peculiaridades objetivas de cada cuadro con la 
resuelve su correspondencia con híbridos de dibujo y carta. En una misiva para aquel galerista relata que habría que posponer para enero de 1962 la muestra, preocupado por su propia promoción pide direcciones de posibles marchantes en América y Europa y menciona ya haber conocido a André Pieyre de Mandiargues. ${ }^{39}$ Notamos también en aquellas cartas de 1960-1962 el hallazgo de la escritura no como texto sino como ornato y composición, esas letras no configuran una oración solamente, concedido tienen el peso específico de cualquier otro rasgo en la composición. Mandiargues, por su parte escribió por primera vez sobre Toledo en "Permanence du sacré" en $1964,{ }^{40}$ a lo cual le seguirían exposiciones en Suiza, Alemania, Inglaterra y Noruega.

A Toledo le interesa a partir de entonces la gráfica en general, lo mismo la estampación que aquellas técnicas que de hecho horadan la matriz. En la gráfica transita del linóleo a la litografía y luego al grabado en hueco, ensaya aguafuertes y combinaciones de técnicas, de la xilografía va al aguafuerte, la mezzotinta se encuentra con la puntaseca. Comienza a volverse sagaz para adivinar los efectos del claroscuro, a adelantar cuándo el proceso de corrosión del ácido sobre la plancha daría como resultado un efecto más o menos intenso, descubre variedad de texturas y tonos con cada placa nueva, se torna estricto consigo mismo.

\section{Gráfica}

La historiografía de la gráfica contemporánea reconoce a William Stanley Hayter (I9OI-I988) como el último y gran innovador del medio impreso y la técnica grabadora. ${ }^{4 \mathrm{I}}$ El rasgo distintivo de su obra está en la adaptación de la écriture automatique de André Masson, uno de los surrealistas con los que

subjetividad que se relaciona con él como personaje, proveer a sus marchantes de tanto como la plaza demande a la par que ventile en variedad de exposiciones sus creaciones.

39. Francisco Toledo, Letter to Antonio Souza (1960), acuarela y tinta sobre papel, $2 \mathrm{I} .1 \times 27.7 \mathrm{~cm}$, David Rockefeller Latin American Fund, MoMA-Nueva York; Department of Drawings and Prints, núm. 82.1970.

40. Mircea Eliade y Carola Giedion-Welckler, eds., XXe Siècle. Permanence du sacré (París: $\mathrm{xx}^{\mathrm{e}}$ Siècle, 1964): 49 .

4I. Peter Black y Désirée Moorhead, The Prints of Stanley William Hayter: A Complete Catalogue (Mount Kisco, Nueva York: Moyer Bell, 1992); Carla Esposito, Hayter et l'Atelier I7 (Milán: Electa, 1990). 
Hayter tuvo cercanía en los años treinta y cuarenta. ${ }^{42}$ El británico podía dibujar libremente con un instrumento tan severo y difícil de manipular sobre superficies duras como el buril. Sus líneas se han comparado con el florilegio y la ligereza del whiplash en el art nouveau. ${ }^{43}$ Modernidad en la gráfica significa el dominio temático de la línea, el hallazgo espacial y multidimensional en la creación de diversos planos al imprimir sobre una misma placa varias veces y con distintos colores, dejando en segundo plano la descripción, la anécdota. Importa más el grabado como técnica, mucho menos lo que se representa.

En el taller de Stanley William Hayter en París, Toledo mira durante un día una práctica para la imprimatura que partía de presupuestos espaciales similares a los de sus maestros y practicantes en México. Hayter mismo publicó en I962 un libro en el que habla de la técnica del grabado, pero también del que podríamos llamar su método docente en aquella cofradía de la estampación de placas y la edición de libros:

no es como el taller tradicional donde invariablemente se reproduce una técnica conocida [...] el trabajo se sigue independientemente y si se pudiera decir que existe instrucción alguna, ésta no obedece a preceptos o prohibiciones, no hay tampoco forma alguna de autoridad [...] los aspectos esculturales del grabado y la impresión nos ocupan [...] y el carácter de ambigüedad espacial resultante de una impresión. ${ }^{44}$

Allí se explora el grabado a color desde diversas viscosidades en la tinta y donde la consecución de "fondos" supera al dibujo o la mímesis. ${ }^{45}$ Por otro lado, la imaginería en aquel taller de la calle Campagne-Première \#17 iba de las criaturas surrealistas a la superposición de planos típica del tachismo. Pero Toledo no se sintió cómodo, existe registro solamente de un trabajo allí producido y a él el Atélier 17 no le provoca mayor recuerdo. Después de allí, su amigo y dueño de la Galería Flinker, lo llevaría del Quai des Orfèvres a la imprenta de

42. David Cohen, "S. W. Hayter. Glasgow and Paris", The Burlington Magazine I3I, núm. IO3I (febrero, 1989): I64-I65.

43. Bryan Robertson, "Our Man in Paris", en The Spectator, Londres, 3 de marzo de 1967, 20.

44. "Unlike the traditional workshops, this Atelier has to do with an idea rather than with a fixed place $[\ldots]$ work is carried on independently [...] and in so far as there can be said to exist any instruction, this is not by precept and interdiction, nor does there exist the voice of authority $[\ldots]$ the sculptural aspects of print-making are perhaps emphasized, and where the special characters of the ambiguity of space in the print." Stanley William Hayter, About Prints (Oxford University Press, 1962), 90-94 (trad. del autor).

45. Black y Moorhead, The Prints of S. W. Hayter, 470. 
Fernand Mourlot donde su obra se desarrollaría de manera muy notable, quizá menos en lo que cada cuadro describe, pero definitivamente en el repertorio de artilugios técnicos y en la exploración de posibilidades con el medio impreso.

En la imprenta de Mourlot, Fernand y su hijo Jacques, patriarcas de aquel negocio, pusieron a disposición de Toledo sus prensas litográficas, placas de granulado de zinc, placas de aluminio y utilería varia. Aunque allí se apreciaba la formación profesional de instituciones como la École Estienne, el aprendizaje ocurría de manera gremial, en la práctica cotidiana y en el intercambio informal de experiencias. ${ }^{46}$ A partir de 1937, Mourlot et Fréres tendría inmejorable prestigio entre los interesados en la gráfica y para 1960 trabajaban ya con Picasso, Braque, Chagall, Dubuffet, Giacometti y Toledo mismo. En Mourlot, además, Toledo pudo ver la serie de estampas taurinas que Picasso hiciera entre 1959-1960. Allí se encargaron, también en 1960, de hacer el tiraje para la gráfica de Marc Chagall (su Biblia del desierto). De modo tal que no es remoto decir que se trata de las primeras influencias que Toledo tuvo al vivir y trabajar en París. En 196r hay una exposición de Georges Braque en el museo del Louvre, Mourlot imprime los carteles publicitarios para la muestra "L'Atelier Braque". Al trabajar en colaboración para dichos carteles y abrevar de la experiencia del personal, Toledo accedería a piedras que provenían de bancos del Danubio; caliza de la cantera de Solnhofen en Alemania, pesadas y de lisura inmejorable. El taller mismo, además, tenía un catálogo de imágenes de prueba y primeras impresiones comparado ventajosamente en esa época con el del departamento de grabado del Museo Británico. ${ }^{47}$ En el Atélier Clot, Bramsen $\&$ Georges de París, Pierre Alechinsky (artista gráfico) y Peter Bramsen (litógrafo) están entre sus primeros colegas e interlocutores. Este último lo describe como: "tímido en extremo". ${ }^{8}$ Toledo comienza a colaborar con Daniel Gervis en 1962 y un año después expondría en su galería del bème arrondisement. En esa imprenta se produjeron entre 1957 y 1964 los cuatro volúmenes del Picasso lithographe. ${ }^{49}$ Toledo estuvo expuesto a todas esas imágenes, es claro en su obra que escogería de allí algunas influencias.

46. Consúltese al respecto Gérard Blanchard y Jean François Porchez, Typo-graphic Design in France from the End of the World War II to the Year 2000 (Lyon: Lettres Françaises, ATypI-Lyon, I998), I72; y, Monographie de l'École Estienne (París: Imprimerie École Estienne, 2000), 228.

47. Francis Ponge, "Matter and Memory", Leonardo 3, núm. I (enero, 1970): 93-95.

48. Gómez Álvarez, El informe Toledo, min. 4'I7”.

49. Fernand Mourlot, Picasso litographe, 4 vols. (Monte Carlo: André Sauret, 1949-1964). 


\section{Obras}

A Toledo entonces no le interesa la temática, sino el medio mismo de la gráfica o la pintura. Los animales y objetos allí representados escapan a un ámbito entre lo denotativo y lo connotativo, es decir, ni se contenta con describirlos ni se ocupa de interpretarlos. Allí hay solamente una muestra, una ejemplificación de lo que observa y le parece relevante. Es al universo privado de Toledo al que nos asomamos. El objeto está siempre a la vista y centrado. Ya sea que el sujeto nos mire o presenciemos solamente el diálogo o intercambio entre los allí involucrados. No es frecuente hallar contrastes de colores complementarios ni armonías cromáticas que anuncien significado. Es el dibujo, la línea misma, la que articula cada cosa representada, los azules, ocres y rojizos acompañan y dan posterior cuerpo a lo observado.

En otros cuadros se manifiesta un palimpsesto de trazos y texturas que sirve al efecto de generar una red, inicial volumetría para cada bulto dibujado, cada animal o persona y cuya función no es la de concertar paisaje en infinita y estricta recesión de planos como en la tradición occidental. Toledo no usa la perspectiva propia en la pintura desde el Renacimiento, la retícula geométrica que sostienen sus espacios en la superficie trabajada es sencilla y de apariencia inocente. Son elementales cruces para un equilibrio central básico. Se establece así una relación equivalente entre el espectador, la escena descrita y el universo al que pertenece lo representado. Allí no hay drama, la contemplación es para un instante detenido.

Característica ostensible de la obra en esos primeros años resulta esa definición implícita que Francisco Toledo hace de la gráfica como medio para conocer lo real oaxaqueño, el oficio del dibujante y lo animal como puente para su cosmogonía. Miremos por ejemplo el caimán que emerge al encuentro de otro lagarto (véase fig. I). Cola y hocico sobresalen del manglar sugiriendo un horizonte. La retícula del cuadro es también el entramado de jungla que se adivina al fondo, detrás del cuadrúpedo (¿un tapir?) que distraído mira su propia imagen en el agua. Toledo logra, esgrafiando la superficie del grabado, diversos efectos que describen ondulaciones líquidas, la textura en el pelaje del herbívoro, así como direccionalidad para los saurios y la animación del instante detenido que observamos en tal acecho. Reducida en complejidad, más textura y forma, nunca perspectiva ni efectismo geométrico, la obra primera de Toledo no parece tener preocupaciones compositivas y está más concentrada en explorar el medio y la técnica (fig. 2). 


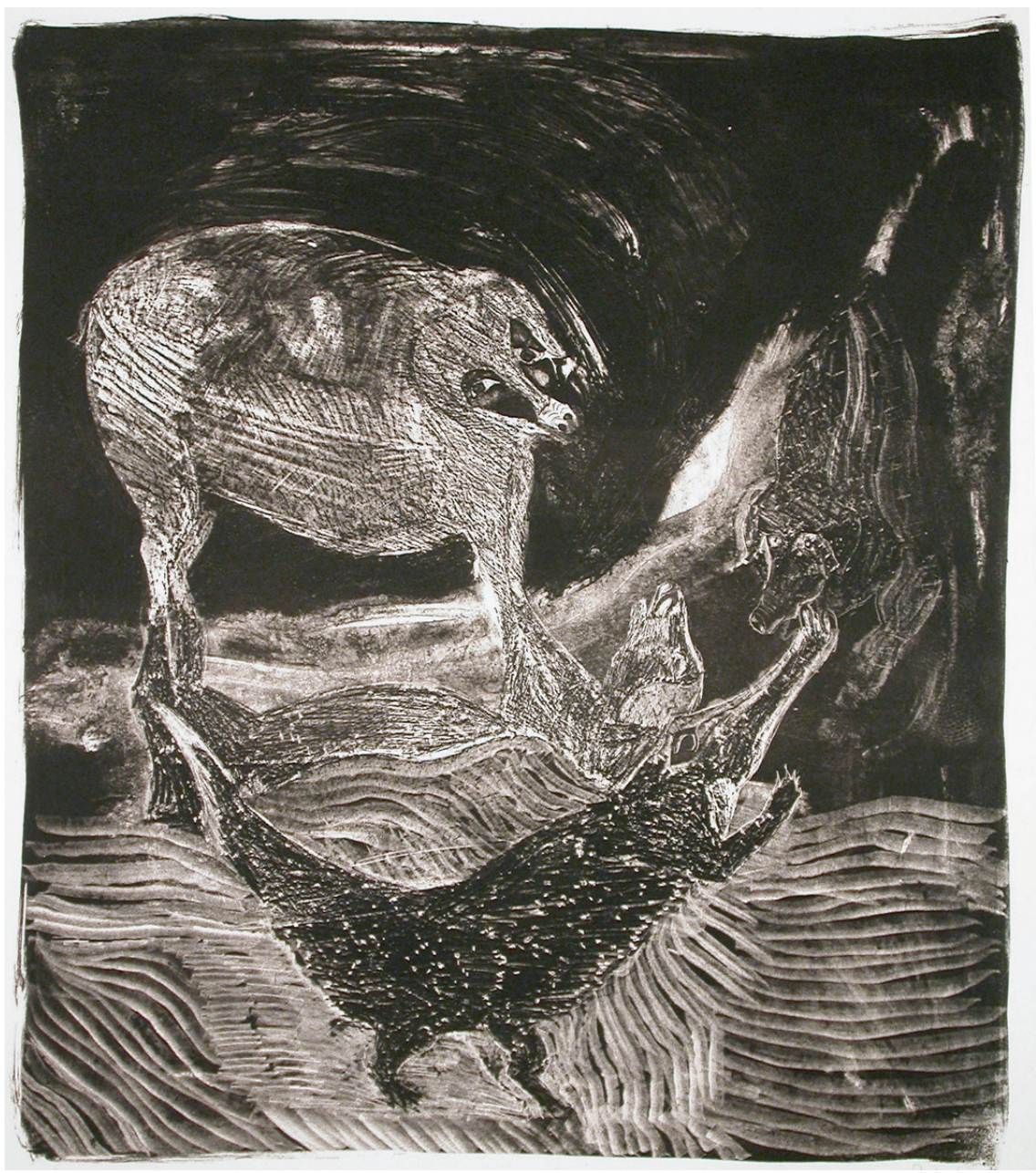

I. Francisco Toledo, Sin titulo, 1960, técnica mixta, $50.8 \times 45.1 \mathrm{~cm}$. Davidson Galleries, Seattle, Washington.

\section{Espacio}

Sus espacios no obstante permanecen sencillos y bidimensionales, aquél es un mundo plano. Y es así, visual y filosóficamente hablando, porque allí se pinta un origen perdido, un ser fundamental y primigenio que ya no es el de este 


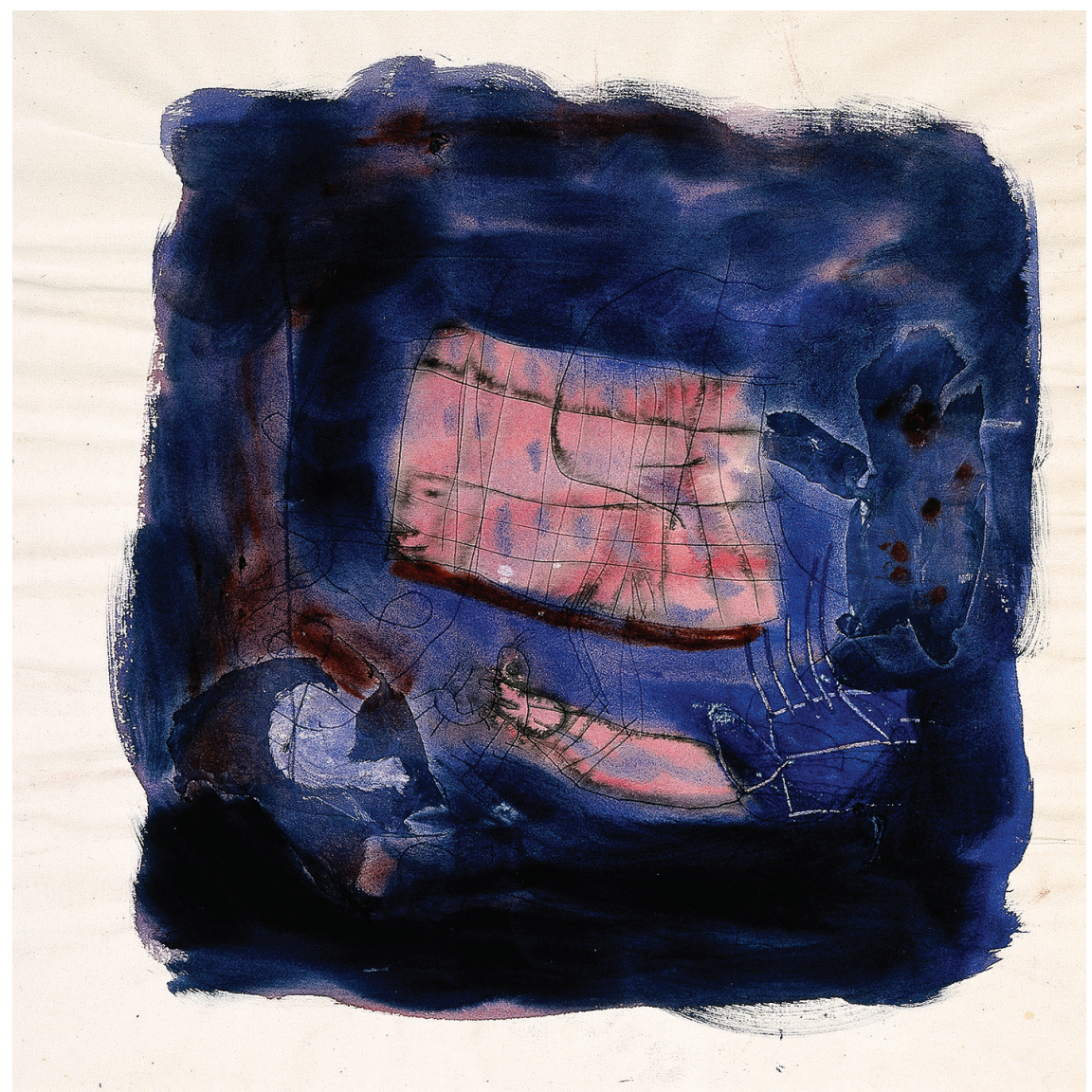

2. Francisco Toledo, Chapulín tocando el arpa, 1959, acuarela y collage sobre papel, $64.5 \times 49.5$ $\mathrm{cm}$. Blanton Museum of Art, The University of Texas at Austin, Gift of Thomas Cranfill, 1973; HCR transfer, 1982. Foto: Rick Hall.

lado del cuadro, allí está el cosmos privado de Toledo, un ámbito zapoteco quizá, lo que parecería indígena y nativo en su pintura, que nos fascina por ajeno y desde el cuadro se recupera sin entenderse del todo su origen. En Chapulín tocando el arpa (fig. 2) hay un trayecto por sensaciones táctiles, se puede adivinar a Toledo aplicando colores aguados rápidamente e impaciente rascando luego la caja y cuerdas del instrumento, las patas del ortóptero. Más que 


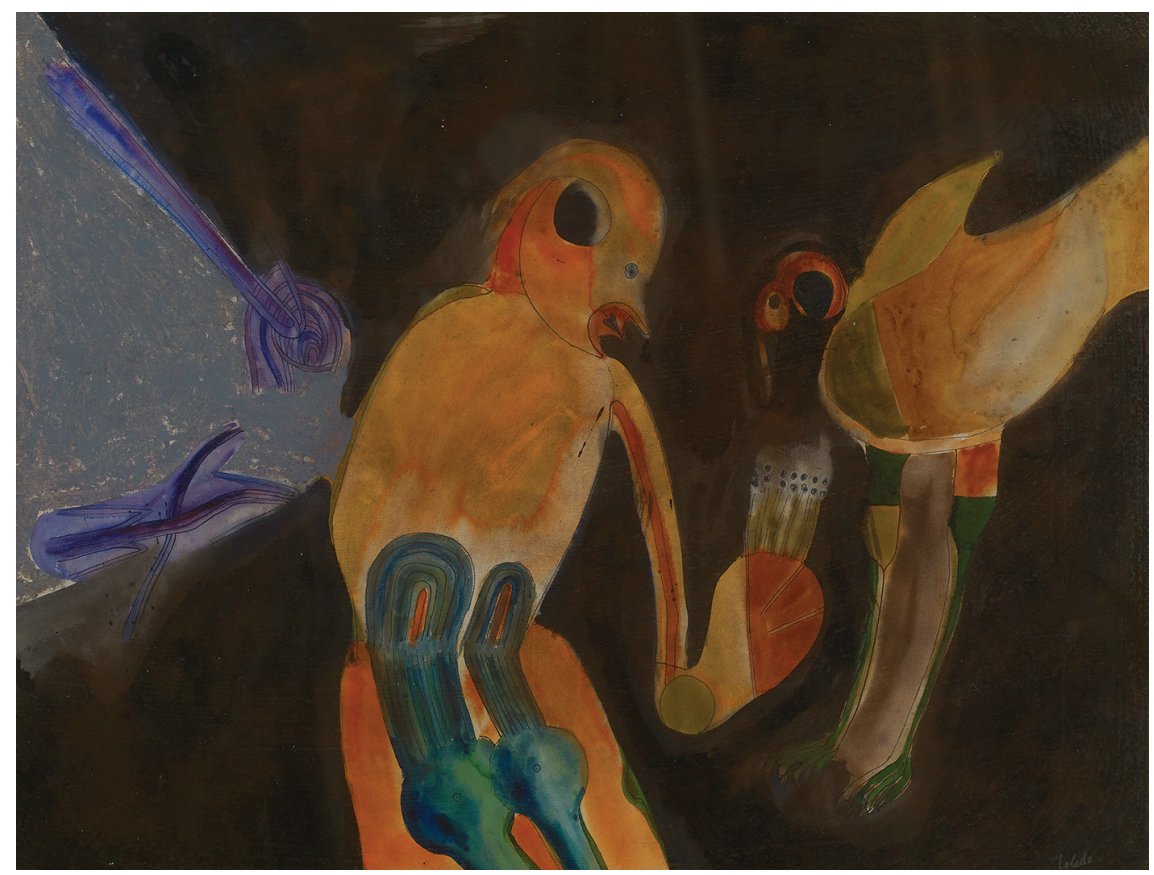

3. Francisco Toledo, Orgía, 1963, acuarela sobre papel, 48×66 cm. Blomqvist Kunsthandel AS, cat. 76, núm. 40688-I.

la señalización específica para un insecto haciendo música, esa pieza constata la diversificación de recursos que el papel admite. El color operó la taumaturgia de crear volumen; húmedo el azul sirve de fondo mientras que cálido el rojo trae consigo al sujeto y al objeto al primer plano.

A veces Toledo se ocupa también de conocer la corporeidad y terreno del papel o tela sobre los que pinta. Ahí, sobre una variedad de papel maché, Toledo aprovecha la absorbencia de ese amasijo de celulosa y fibras pulposas para impregnar zonas de color hasta lograr una consistencia sólida de apariencia casi pétrea cuando la superficie se ha secado. Está más interesado en averiguar cómo se comporta el papel y menos en los personajes allí enmarcados. Tal es la cantidad de tinta que chupó el macerado, que el dibujo se ha perdido y predominan áreas de tinte y recomposición del papel con dichos matices. Ése es el caso de Orgía, realizada en Noruega (fig. 3). 
Frecuentemente el soporte físico para cada dibujo es papel encontrado, no parece haber método ni cuidado al escogerlo. Es mero e inmediato pretexto para pintar otra vez, se diría que el reflejo es representar y explorar el sustrato, la superficie y su narrativa son lo de menos. La pluma recoge y arrastra tintas sobre papeles de formatos irregulares, incluso incidentales, literalmente pedazos. Emplea estos instrumentos de escritura como gubias, no desliza sino que rasga, presión apenas que no logra romper la hoja que labra. Ello le confiere además a cada obra una cualidad auditiva, allí donde la labor precisa de cada línea se aprecia como un ejercicio de una contextura muy específica. Cada trazo se antoja rascado, tallado casi, hay allí un rumor, un ruidito que Toledo provoca hurgando en la materia y sacándole algo que es papiro o madera. Esa materialidad que le importa está más allá de lo que sus líneas describen, es un contenido metapictórico, pero igualmente relevante.

\section{El mundo del arte}

Toledo es un hombre de su tiempo pese a su impostado aislamiento provincial, esa actitud que lo convierte en personaje asumido a la vuelta de París en 1965, identidad creada luego de conocer a la pareja de los Mandiargues y mirar cómo opera el matrimonio de los Tamayo al pintar y vender. Desde entonces Toledo tuvo claro que el mercado del arte es ineficiente. Es decir, que no opera como el capitalismo lo consideraría óptimo. Dicho mercado se compara favorablemente con cualquier otro nicho financiero en el que se invierta esperando ganancia. El del arte es anómalo, ya que no obedece leyes de precios, se comporta de manera inesperada en subastas y el solo renombre de un artista basta para asegurar capital y rendimientos en una oferta dada. ${ }^{50}$ Donde Tamayo comercializa ya al precio que quiere y seduce en el circuito de las Naciones Unidas que discursivamente al menos le ofrece contrapeso a la retórica confrontacional de la guerra fría, Toledo resulta intrigante, y, por original, incomprendido. Rufino Tamayo pinta con sofisticación y elegancia, su habilidad es la de agradar, mientras que Toledo resulta un mexicano distinto, inasible y cru-

50. James E. Pesando elabora una corrida financiera con datos de Sotheby's, Christie's y varias galerías parisinas y neoyorquinas especializadas en gráfica moderna, entre 1961 y 1992, donde uno de los índices es justamente la obra de Toledo; véase James E. Pesando, "Art as an Investment: The Market for Modern Prints", American Economic Review 83, núm. 5 (1993): I075-I089. 
do. ${ }^{5 \mathrm{I}} \mathrm{Y}$ ése será otro valor agregado que el mercado encuentre en la obra de este extraño oaxaqueño. La fortuna acompaña a Toledo tras participar en ese ritual de paso y aceptación que consagra a un artista emergente en el París de 1963, el XIX Salón de Mayo en el Museo de Arte Moderno.52

Edward W. Said ha descrito el exilio como la incurable herida provocada a un hombre cuando el sentido de pertenencia, el origen y la identidad se hallan en sitios distantes. Sin embargo, suele ocurrir a estas víctimas del desarraigo una lucidez intelectual que resulta en renovador contrapunto a cada entidad cultural a la cual hacen referencia (la propia, la adoptada y acaso aquella que los obligara al extrańamiento). 53 Toledo desarrollará desde entonces un corpus de obra que no admite interpretación localista y se propugna universal, anterior a la historia del arte misma, ahistórica en su índice a formas netamente humanas de expresión. La suya es una operación epistémica similar a la que incluye en la tradición mesoamericana a Rufino Tamayo, así explicada por Paul Westheim en los años cuarenta. ${ }^{54} \mathrm{En}$ ambos casos, aunque la estética tenga un regusto zapoteca y por el que suele empezarse todo intento de comprensión, la proposición plástica que ambas obras proyectan es ulterior, allí donde precolombino y moderno dejan de tener sentido por ser limitantes coordenadas espacio-temporales. ${ }^{55}$ Si la materialidad del color da como resultado una semiótica oaxaqueńa, aun si el bestiario pareciera de microcosmos, el asunto último en la pintura de Toledo es justamente la representación, la posibilidad inmanente que el ser humano tiene al crear. Toledo es siempre figurativo pese a no ser nunca realista. Y allí el quid que lo distingue de la generación previa de artistas en México, lo mismo los consagrados, que sus maestros.

51. Entre los autores que han calificado a Tamayo de "fácil", cito a Bernard S. Myers, "Tamayo versus the Mexican Mural Painters", College Art Journal I3, núm. 2 (I954): IOI-I05; Luis Camnitzer, Conceptualism in Latin America: Didactics of Liberation (Austin: University of Texas Press, 2007), 2 y ss.

52. Véase (XIX $)$ Salon de Mai. Musée d'Art Moderne de la Ville de Paris, du 28 avril au 19 mai 1963 (París: P.P.I., I963); Sylvia Navarrete, "Francisco Toledo", en Maestros del Arte Contemporáneo en la colección permanente del Museo Rufino Tamayo, Raquel Tibol y Samuel Morales, eds. (México: Américo Arte Editores/Fundación Olga y Rufino Tamayo/Instituto Nacional de Bellas Artes, 1997), 214-218.

53. Edward W. Said, Reflections on Exile and other Essays, Convergences (Cambridge, Massachusetts: Harvard University Press, 2002).

54. Peter Chametzky, "Paul Westheim in Mexico: a Cosmopolitan Man Contemplating the Heavens”, Oxford Art Journal 24, núm. I (enero, 200I): 23-44.

55. Martín Martín Fernando, "Francisco Toledo o el demiurgo fabulador", Laboratorio de Arte, núm. I2 (I999): 415-428. 
Para 1959 cuando Toledo se afinca en París, el "art-autre" era un término útil para ubicar a aquellos artistas sin compromiso ideológico o programa estético, vagamente asociados a la figura de Michel Tapié y entusiastas del tachismo. ${ }^{56}$ Allí es donde primero lo ubican críticos y comentaristas, pero muy pronto esa definición se vuelve equívoca e insuficiente. Jean Dubuffet había sido un descubrimiento de Clement Greenberg en 1946.57 Se trata del único artista de vanguardia en la posguerra parisina que no puede ubicarse o definirse a partir de una toma de posición estrictamente ideológica. ${ }^{58}$ En el instante que Toledo mira la obra de Dubuffet constata dos convicciones suyas, y que se pueden intuir desde que deja México: por un lado, la necesidad de conocer más sobre las posibilidades técnicas de la gráfica, y por otro, un método de origen surrealista en el que el "automatismo" ofrece posibilidades interesantes. El encuentro con Dubuffet lo ayuda a separarse de paradigmas artísticos, mientras que otro hallazgo, el del suizo Paul Klee, lo invita a seguir el camino de una estética de apariencia infantil e inocente en aras de un paisaje pintado que le resulte propio y auténtico. De Rufino Tamayo, individuo reservado en lo personal pero muy claro al hacer declaraciones sobre su contexto y el arte, Toledo recoge una actitud con la que se podía difuminar el compromiso doctrinario que aquel contexto parecía exigir, optando mejor por una condición universalista que en su indiferencia por "la grilla" deshistoriza y quita yugo propagandístico a la práctica de un artista.

\section{Geopolitica}

Ni México ni el arte eran ajenos al conflicto que la bipolaridad geopolítica de posguerra implicaba a finales de los años cincuenta. El Pabellón de nuestro país

56. Sobre el art autre y el tachismo véase el texto introductorio de Frank O'Hara, New Spanish Painting and Sculpture: Rafael Canogar and Others, catálogo de la exposición (Nueva York: The Museum of Modern Art/Doubleday, 1960), III. Por otro lado, quien mejor ha trazado esa ruta que Toledo toma luego de conocer el tachismo es Danielle Chapleau, "Que restera-t-il de nous?", tesis de maestría (Québec: Université Laval-Faculté d'Aménagement, d’Architecture, Arts Visuels et Design, 2007), 89 .

57. Clement Greenberg, "Pierre Matisse's Big Four", Newsweek. The Magazine of News Significance (20 de mayo de 1946): I02.

58. Serge Guilbaut, "Postwar Painting Games: the Rough and the Slick", en Serge Guilbaut, ed., Reconstructing Modernism: Art in NewYork, Paris, and Montreal, 1945-1964 (Cambridge, Massachussetts: MIT Press, I990), 33. 
en la Feria Mundial de 1958 da cuenta de cómo el discurso de relaciones exteriores y el programa plástico de una nación deben ajustarse necesariamente a aquel pleito de hegemonías. ${ }^{59}$ Ello debía resolverse en tres planos, el nacional, el continental y el mundial. Ejemplo de ello son el continuum que Chávez Morado traza en los muros del Centro Médico (1958) entre la medicina prehispánica y la actualidad de fisiología nuclear y farmacéutica industrial; la I Bienal Interamericana de Grabado y Pintura en el Palacio de Bellas Artes, donde 2I países ventilaron posiciones diversas desde el "misoneísmo" hasta la más cordial universalidad; ${ }^{60}$ finalmente véase al mestizo mexicano abrazar la era atómica en la pared del edificio nacional próximo al Atomium de Bruselas. ${ }^{61} \mathrm{La}$ consigna que Fernando Gamboa tenía para aquella puesta en escena era "responder a un concepto de realismo moderno". Es decir, sin apartarse de sus preferencias figurativas y sin contravenir la corriente ideológica del "nacionalismo revolucionario", el máximo operario de la política cultural en México no tiene más remedio que admitir geometría, abstracción y síntesis como valores plásticos; libertad, universalismo e individualismo como temas. Donde el discurso implícito de aquella selección plástica propagandiza el realismo muralista reputado como representación de un régimen liberal, su contenido y repertorio técnico hablaban de vanguardia abstraccionista a la manera del MoMA y sus colecciones. A decir de Ana Garduño el arte estaba decretado desde Washington en lo político y desde Nueva York en lo visual. ${ }^{62}$

A partir de 1950 proliferaron encuentros entre países de América y Europa donde la divisa eran programas de intercambio cultural, particularmente exposiciones de arte. Sin embargo, estos gestos de buena voluntad eran justamente tácticas diplomáticas del momento. Para el United States Information Service estos eventos y su difusión eran vitales para cambiar el modo de pensar de intelectuales, artistas y entusiastas de la cultura (usuales convencidos de

59. Diana Briuolo Destéfano, "Guerra Fría en Bruselas: México en la Exposición Universal de 1958”, Discurso Visual, núm. I3 (julio-diciembre, 2009), consultado el I9 de noviembre de 2013, en http://discursovisual.net/dvwebiz/.

6o. Xavier Moyssén, "La Primera Bienal Interamericana de Grabado y Pintura”, Anales del Instituto de Investigaciones Estéticas VII, núm. 28 (1959): 77-8I.

6I. Ana Garduño, "La ruptura de Fernando Gamboa", Discurso Visual, núm. i6 (enero-abril, 20II), consultado el 2I de noviembre de 20I3, en http://discursovisual.net/dvwebi6/aportes/ apoana.htm.

62. Ana Garduño, "Fernando Gamboa, el curador de la guerra fría", en Fernando Gamboa, el arte del riesgo, catálogo de la exposición (México: Consejo Nacional para la Cultura y las ArtesInstituto Nacional de Bellas Artes-Museo Mural Diego Rivera, 2009), I7-65. 
izquierda) ${ }^{63}$ Francisco Toledo vio con claridad ese jaloneo en México y en el extranjero. El sitio al que llegó, París, era ni más ni menos que el ruedo donde este pleito se dirimía. Allí Alfred H. Barr, René d'Harnoncourt y Jean Cassou habían acordado las exposiciones "Modern American Painters and Sculptors" y "50 Years of American Art". ${ }^{64}$ En el mismo lugar que tenía atronador éxito el Ballet Bolshoi soviético dirigido por Igor Moseyev. Mientras tanto en Manhattan, George Balanchine creaba para el New York City Ballet su archifamosa versión del Cascanueces de Piotr Ilich Chaikovsky. Cada escenario y museo que ocupaban con sus triunfos las potencias era una más de las estratagemas con las que se peleaba aquel conflicto.

Entre 1955 y 1959 el MoMA de Nueva York presentó en París dos exposiciones de arte y diseño contemporáneos. ${ }^{65}$ En ellas se hacía especial énfasis en el expresionismo abstracto y las directrices de consumo material e interiorismo del American way of life promovido por las compañías de diseño industrial norteamericanas (Tupper Corporation, Knoll y Hermann Miller, entre otras). Es muy probable que si Toledo no viera ninguna de ellas, sin duda escuchara de ellas como recientes eventos en el mundo del arte al que llegaba. El contraargumento, se diría, fue planteado un año después por la Galería Charpentier con su exposición "Cent Chefs d'oeuvre des peintres de l'École de Paris” y que presentó obra decimonónica, además de obra de los nabis, los fauves, cubismo y surrealismo. Para su sección contemporánea se presentó obra de Marc Chagall, Hans Hartung, Roberto Matta y André Masson. Este último era quien de manera más explícita defendía que el surrealismo había muerto con la segunda guerra mundial y en América, y que su extensión lógica como dispositivos técnicos eran el action painting y l'automatisme. ${ }^{66}$

Ese mismo pleito ideológico donde la apuesta abstraccionista se oponía al realismo preeminente en el mito de los Tres Grandes la reseńa debidamente Raquel Tibol, en una serie de artículos aparecidos en "Diorama de la Cultura” en el periódico Excélsior bajo el título “¿Sobre qué discuten los pintores

63. Gay R. McDonald, "The Launching of American Art in Postwar France: Jean Cassou and the Musée National d'Art Moderne”, American Art I3, núm. I (primavera, 1999): 40-6I.

64. Serge Guilbaut, How New York Stole the Idea of Modern Art. Abstract Expressionism Freedom, and the Cold War (The University of Chicago Press, I985), I47-I54.

65. Gay R. McDonald, "Selling the American Dream: MoMA, Industrial Design and PostWar France”, Journal of Design History I7, núm. 4 (diciembre, 2004): 397-4I2.

66. Kathleen Morand, "PostWar Trends in the École de Paris", The Burlington Magazine Io2, núm. 686 [Modern Painting] (mayo, 1960): I87-192. 
mexicanos?". ${ }^{67}$ Las notas aparecen en paralelo a la I Bienal Interamericana de Pintura y Grabado y las conferencias que organizó el Frente Nacional de Artes Plásticas para ventilar sus opiniones desde las revistas Artes Plásticas y Artes de México (fundadas en 1953 y diseñadas por Vicente Rojo). En diciembre de 1958 Salas Anzures fue nombrado jefe del Departamento de Artes Plásticas y Chávez Morado, director de la Escuela de Artesanías. Posiblemente Toledo compartiera, aunque quizá de un modo menos virulento y articulado, la opinión que prevalecía entre los entusiastas del galerismo en las calles de la Zona Rosa, ese ambiente y convicción en los negocios de Mariana Amor y Antonio Souza. Aquél era un sentir que recogería Socorro García en un reportaje: “¡es que no había un solo brote, una nueva expresión que se diferenciara de la manida escuela realista socialista, exhaustivamente representada por maestros, discípulos, imitadores, mixtificadores, etcétera?" 68

\section{Tamayo}

Luego de haber pintado el Prometeo trayendo el fuego a la humanidad para la Sala de Conferencias de la Unesco en París-Fontenoy en 1958, y otros cuadros de menor formato, Tamayo exploraba una suerte de efecto gestalt donde la figura se torna fondo y viceversa. ${ }^{69}$ Quizá Toledo aprendió allí ese truco; después de la exposición individual de Tamayo en la Galérie de France en 1960 son comunes también en él esos juegos. Tamayo y Toledo probablemente discutieron y tuvieron puntos de encuentro respecto a cómo se resuelve un cuadro. En su exposición parisina Tamayo enuncia que no hay bocetos, se trabaja directo sobre la superficie última; lo más importante en el cuadro, aquello que le da estructura, es la textura del plano, el material mismo ya sea tela o papel; la paleta es limitada por necesidad, su variedad depende de la manipulación de la materia pictórica y no de la aplicación de cuánto color esté a la mano. ${ }^{70}$

67. Raquel Tibol, “¿Sobre qué discuten los pintores mexicanos?”, en suplemento "Diorama de la Cultura”, de Excélsior, 23 de marzo, 6 y 20 de abril y in de mayo de I958, año XLII, t. III, núms. I498I, I4995, I5009 y I5030.

68. Socorro García, "La Galería de Antonio Souza: una lección para los burócratas del arte", en suplemento "México en Cultura", Novedades, núm. 494, 7 septiembre de 1958, 6. 69. José Corredor-Matheos, "El espacio sagrado”, en Rufino Tamayo (Barcelona: Polígrafa, I987), I6-I7. 70. Jacques Lassaigne, "Estudios y elección”, en Jacques Lassaigne y Octavio Paz, Rufino Tamayo, 33-36. 
La textura, la dimensión táctil en la superficie de la pintura de Toledo es acaso aquello que podríamos llamar su pathos. Es ésa que Teresa del Conde llamó en Toledo su "conciencia memoriosa... [para] ... desarrollar contenidos arcaicos" ${ }^{7 \mathrm{II}} \mathrm{El}$ ethos en consecuencia es ese canon que parece derivar del diálogo con Tamayo o del descubrimiento de Dubuffet.

Octavio Paz escribió entonces que el placer de mirar necesariamente ha de convertirse en un juicio. En ese mismo texto caracteriza la obra misma de Tamayo como un acto de crítica. Se trata de un argumento a partir del cual Paz separa a Tamayo de sus contemporáneos y que funciona igual si uno se explica cierta ruta compartida con Toledo; la heterodoxia como opción consciente, el escape al estilo preponderante de su época y la soledad como búsqueda de un lenguaje propio. En ambos pintores se advierte como influjo "la poderosa figura aislada de Dubuffet" y el rigor plástico como investigación fundamental. $7^{2}$ Para la crítica fuera de México en la década de los cincuenta, Rufino Tamayo era el responsable fundamental de haber dirigido el arte en México por la vía del caballete, la pintura misma y alejándose de la función discursiva del mural y la revolución ilustrada. ${ }^{73}$ No es entonces una sorpresa que Toledo viera como parada necesaria en su peregrinaje la visita al maestro oaxaqueńo, el campeón de la disidencia frente a los Tres Grandes y los usos que ideología y Estado hacían tanto de su obra como de su fama.

\section{Autoria}

La línea es el elemento básico y fundamental de toda representación. Es el potencial expresivo detrás del mínimo trazo, ya sea escrito o dibujado. En esa línea se refleja un carácter individual específico para el autor del texto o cuadro que se esté considerando. Se trata por igual de "la letra", de las peculiaridades en la escritura, que del estilo dibujístico de cualquier persona. Con base en ello se puede plantear una progresión que va de lo concreto a lo abstracto y que se observa en las líneas de Francisco Toledo signando su nombre en

7I. Teresa del Conde, "Francisco Toledo. Los poderes creativos", Vuelta, núm. 234 (mayo, I996): 58-6I.

72. Octavio Paz, "Rufino Tamayo. Transfiguraciones", en Octavio Paz, III, México en la Obra de Octavio Paz 8, Los privilegios de la vista, vol. 2: Arte de México Arte del siglo xx (México: Fondo de Cultura Económica, $2^{\mathrm{a}}$ ed., 1989), I27-I28 y I44-I45.

73. Myers, "Tamayo versus the Mexican Mural Painters", Ioo-IO5. 
cada obra entre 1959 y 1962 aproximadamente. La firma del artista identifica primero la autoría, enseguida incide en el reconocimiento que hacemos de tal creación. Allí ese trazo distintivo se escinde de ser mero nominal para un individuo realmente existente y se transforma en la denominación específica de un creador en particular. Después y de manera independiente de nuestra mirada o consideración, la firma se vuelve marca en el sentido de derecho de explotación comercial, pero también de exclusividad, constata con su peculiar forma la primera verificación rumbo a ubicar propiedad intelectual y constreñir el uso de toda índole. Por último, esa rúbrica dirige hacia la noción de "originalidad", función que se desprende de la cláusula anterior, además de conferirle la problemática e inescapable "aura" benjaminiana. Este autógrafo es un gesto individual y en primera instancia espontáneo. Muy pronto se torna en rasgo elegido, signo consciente que ubica como única cada imagen u objeto que identifica. La firma del artista se halla entonces a la mitad del camino entre el dibujo, la caligrafía y la escritura automática, no es aquella operación alfabetizada e inteligente que construye una a una las letras necesarias y suficientes para escribir o leer un nombre, tampoco reconfigura como imagen ninguna realidad observada. ${ }^{74} \mathrm{La}$ firma es justamente esa relación, el emblema caligráfico que Toledo adapta y adopta para reconocer su obra. Incluso existen estudios de psicología que sustentan correlaciones válidas entre esta línea y la personalidad, grafología que arrojaría luces sobre el fuero interno del artista legible desde su dibujo, su firma, sus "trazos conectivos" como se les ha definido. ${ }^{75}$

Así la firma, el "Toledo" resuelto en dos o tres giros del lápiz, es un gesto plástico reconocible y desde entonces repetido, trazo semiautomático y ya no escritura, para dejar un índice de su apellido. Ahora ha aprendido a emblematizar la identidad artística, tal signatura tiene parentesco con el modo en que Picasso señala y pone sello autoral a cada una de sus obras. Es decir, Toledo abstrae el acto de escribir las seis letras de su alter-ego artístico y convierte el gesto de la rúbrica en un diseño identificable y simple (fig. 4).

74. Lorettan Devlin-Gascard, "The Signature as an Access Line to Expressive Drawing", Art Education 50, núm. 2 (marzo, 1997): 39-44.

75. Anne Haas Dyson, "The Emergence of Visible Language: Interrelationship between Writing and Drawing", Visible Language I6, núm. 4 (1982): 360-381. 
4. Firmas de Francisco Toledo.
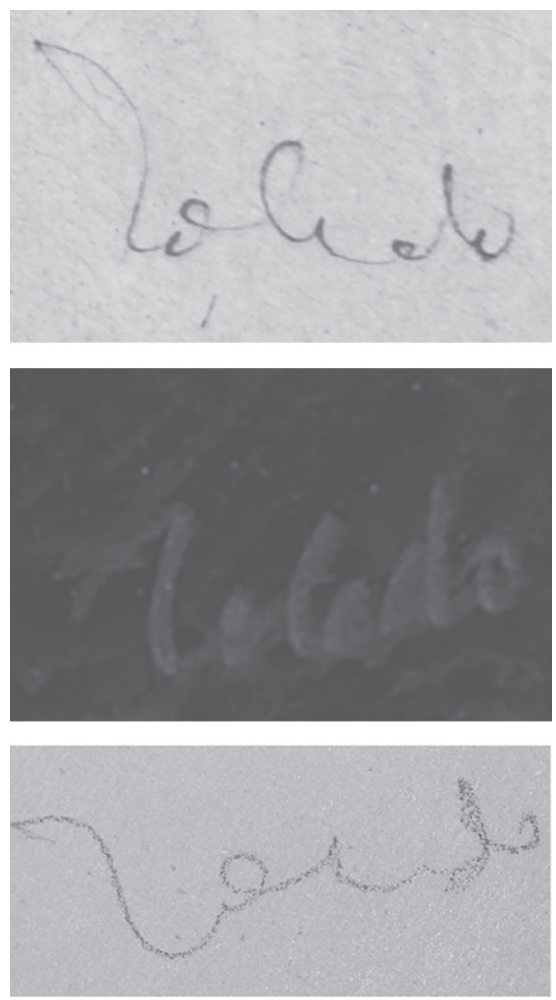

\section{Epilogo}

Cuando Cardoza y Aragón ensayó a explicar la pintura de Francisco Toledo comenzó por hacer una aclaración básica. Para él la representación tiene una cualidad metapictórica, es decir, un componente de significado que de lo visual no admite traducción a palabras y que puede solamente entenderse en términos plásticos. Aunado a ello parecía encontrar una cohesión narrativa, congruencia iconográfica y sensación generalizada de pertenencia en todo aquello que pintaba. Es decir, las características esenciales de un universo mitológi$\operatorname{co.}^{76} \mathrm{Si}$ el mito se halla de aquel lado del linde de lo que puede ser historizado

76. Cardoza y Aragón, Ojo/voz, 83-85. 
y representado, ese ámbito es justamente la demarcación, el término espaciotemporal que da principio a lo humano y se ofrece sólo como narrativa. La mitología nos informa a los hombres de un universo divino y prehistórico que no cambia. La realidad desde la que hacemos referencia a aquello está en eterna transformación y es diametralmente opuesta a la esfera preternatural. Ese algo ulterior al género humano, "primitivo arte sacro" le dice Cardoza, es un aprendizaje que Toledo tuvo, expuesto a la narrativa universal del arte y a su origen último, ambas expresiones que vio en París, en el palacio del Louvre y en el Musée de l'Homme. ${ }^{77} \mathrm{Su}$ arte entonces tendrá la función mesiánica, anunciada y necesaria, de divorciar a la representación en México de su nacionalismo, desde dos vías: la primera de complejidad técnica y elaboración abigarrada, la segunda de coloquial y asequible temática. Es decir, elevar el arte como hacer y simplificar su aproximación como contenido; "artesano diverso y minucioso" lo llamó Cardoza. ${ }^{78}$ \&

77. Luis Cardoza y Aragón, Pintura contemporánea de México (México: ERA, 1974), 29-30.

78. Angélica Abelleyra, Se busca un alma. Retrato biográfico de Francisco Toledo (México: Plaza y Janés, 200I), 35-38. 